Studia i Materiały, 2013 (16): 91-102 ISSN 1733-9758, () Wydział Zarządzania UW

DOI 10.7172/1733-9758.2013.16.6

\title{
Skutki kryzysu finansowego w Wielkiej Brytanii
}

\author{
Tomasz Lechowicz*
}

Trwajacy w latach 1995-2007 boom mieszkaniowy miat wplyw na politykę banków odnośnie do udzielania kredytów. Banki zwiększaty akcje kredytowa i zmniejszały stope rezerw. Staty się bardziej chętne do udzielania kredytów hipotecznych (UK House Prices). Byta to sytuacja bardzo niebezpieczna, gdyż w przypadku wystapienia kryzysu mogła poważnie zagrozić plynności finansowej instytucji z rynku finansowego na rynku angielskim.

Słowa kluczowe: kryzys, bank, kredyt, Wielka Brytania, makroekonomia.

Nadesłany: 1.11.2013 | Zaakceptowany do druku: 24.11.2013

\section{The effects of the financial crisis in the UK}

The ongoing from 1995 to 2007 housing boom had an impact on the policy of banks for lending. Banks increased lending and reduced the reserve ratio. Have become more willing to lend mortgage (UK House Prices). It was a very dangerous situation, because in the event of a crisis, could seriously jeopardize the financial liquidity of the financial market institutions on the English market.

Keywords: crisis, bank, credit, UK, macroeconomics.

Submitted: 1.11.2013 | Accepted: 24.11.2013

JEL: A12, A13, A14, L10, Z18, Z19

\section{Wstęp}

Światowy kryzys gospodarczy wpłynął nie tylko na uczestników rynku finansowego, lecz także odcisnął swoje piętno na funkcjonowaniu całej gospodarki Wielkiej Brytanii. Pojawiające się zjawiska kryzysowe na rynku finansowym w Wielkiej Brytanii spowodowały spowolnienie gospodarcze. Kryzys finansowy wpłynął negatywnie na Produkt Krajowy Brutto poprzez jego następujące części składowe: inwestycje, konsumpcję, wydatki rządowe oraz eksport netto.

W artykule przedstawiono, wykorzystując dostępne dane empiryczne, skutki kry- zysu w skali makroekonomicznej, a także działania antykryzysowe przeprowadzone przez Wielką Brytanię. Badania obejmują okres 2001-2013, który został wybrany by pokazać sytuację makroekonomiczną w Wielkiej Brytanii po wystąpieniu kryzysu finansowego.

Przedmiotem analizy w artykule są przede wszystkim dane makroekonomiczne, takie jak PKB, dług publiczny, deficyt budżetowy, inwestycje, wydatki rządowe oraz eksport. Nie wyczerpuje to zestawu czynników makroekonomicznych determinujących sytuację gospodarczą Wielkiej Brytanii, jednak z punktu widzenia autora

\footnotetext{
* Mgr Tomasz Lechowicz - Uniwersytet Ekonomiczny w Krakowie.

Adres do korespondencji: Top Flat, 1 Bell Street, Shaftesbury, SP7 8AR, Dorset, England; e-mail: tomek1278@op.pl.
} 
są to te najważniejsze. W artykule został również przedstawiony model Hymana Minsky'ego, który pokazuje, jak powstaje bańka spekulacyjna.

\section{Bańki spekulacyjne (modele baniek spekulacyjnych, w tym model Hymana Minsky'ego)}

Zachowania inwestorów nie zawsze sa racjonalne (oparte na oczekiwaniach, które dotycza przyszłego kształtowania się czynników fundamentalnych) - obrazują to tworzące się od czasu do czasu na rynkach akcji bańki spekulacyjne.

$\mathrm{W}$ początkowej fazie boomu giełdowego inwestorzy podejmują decyzje na podstawie analizy czynników fundamentalnych. Źródłem ich optymizmu są oczekiwania na wzrost wydajności oraz zysków przedsiębiorstw. Racjonalną przesłanką formułowania takich oczekiwań jest zazwyczaj sytuacja, w której szybkiemu wzrostowi gospodarczemu towarzyszy niska inflacja. Tworzy to bowiem podatny grunt dla pojawienia się wśród inwestorów przekonania, że w gospodarce dokonuje się przełom technologiczny, który przynosi trwały wzrost wydajności, a tym samym trwały wzrost spółek giełdowych i wypłacanych przez nie dywidend (Ofek i Richardson, 2003, s. 1113-1137).

Po pewnym czasie boom może się jednak przekształcić w sytuacje określoną jako bańka spekulacyjna, gdy głównym powodem zakupu akcji staje się już tylko sam wzrost ich cen. Oczekiwania inwestorów przestają być racjonalne. Przestają być wynikiem oczekiwań dotyczących przyszłego kształtowania się czynników fundamentalnych. Akcje kupowane są już głównie dlatego, że ich indeks rośnie.

W miarę jak ceny akcji rosną w inwestorach zaczyna umacniać się wiara w trwałość trendu. Im dłużej trwa wzrost cen akcji, tym bardziej są gotowi wierzyć, że trend się utrzyma. Zaczynają oni przywiązywać coraz większą wagę do wyjaśnień i zdarzeń, które tę ich wiarę uzasadniają. Zwracaja mniejszą uwagę na informacje, które mogą świadczyć, że kierunek trendu może się zmienić. Wiara w trend wynika z przyczyn prozaicznych.

Przyspieszenie procesu formowania się bańki spekulacyjnej następuje wtedy, gdy spekulacja, jak pisze Charles Kindleberger (1999, s. 25) „wciąga także tych, którzy zazwyczaj trzymają się od niej z daleka".
Im bardziej rośnie wskutek tego siła wzrostowego trendu, tym mniej jest odważnych, by sprzedawać akcje czy inne dobra, w tym także nieruchomości.

Zgodnie $\mathrm{z}$ teorią kryzysu finansowego wg Mińskiego, model powstawania baniek spekulacyjnych opiera się na założeniu zmienności podaży kredytu i jego nadmiernej kreacji. Model ten wyróżnia następujące etapy powstawania bańki oraz załamania finansowania (Nawrot, 2010, s. 11-14): - rozbudzenie gospodarki za pomocą pojawienia się wewnętrznego wstrząsu - w przypadku obecnego kryzysu są to nowe możliwości inwestowania;

- środki zaczynają być lokowane w coraz to nowsze obszary inwestowania, w związku z powyższym popyt w danym sektorze rośnie, podaż natomiast nie spełnia zapotrzebowania rynku, czego następstwem jest wzrost cen;

- skłonność do zadłużania się przedsiębiorstw oraz gospodarstw domowych rośnie, pierwotnie w celach konsumpcyjnych, następnie inwestycyjnych, ostatecznie spekulacyjnym;

- awersja do ryzyka spada, w związku $\mathrm{z}$ powyższym rośnie nasycenie rynku, a także jego przeszacowanie, w rezultacie czego powstaje bańka spekulacyjna.

Model Minsky'ego dotyczy zachowania kredytobiorców i banków. W pierwszej fazie kryzysu finansowego zarówno w bankach, jak i u kredytobiorców wzrasta optymizm, który prowadzi do niedoszacowania ryzyka kredytowego wśród banków oraz podwyższania prognoz rentowności inwestycji wśród kredytobiorców. Następnie ${ }^{1}$ :

- banki zwiększają limity kredytów dla firm oraz gospodarstw domowych, walczą na rynku kredytowym o klientów oraz zmniejszają awersję do ryzyka;

- gospodarstwa domowe zaciągają kredyty na zakup nieruchomości (pierwszy zakup lub kolejny zakup nieruchomości w celach inwestycyjnych) bądź kredyty konsumpcyjne; przedsiębiorstwa zaciągaja kredyty inwestycyjne na zakup aktywów w celu osiągnięcia zysków - na tym etapie powstaje spekulacja.

Według Minsky'ego następuje teraz proces zwany follow the leader, polegający na włączaniu w spekulacyjny wyścig nowych podmiotów, które, widząc zachowania innych uczestników, również chcą skorzystać z nadarzającej się okazji. W ten sposób tworzy się bańka spekulacyjna. 
Definicje bańki spekulacyjnej, a także powyższe rozważania wskazują zwykle, że pojawia się ona, gdy ceny aktywów (zwłaszcza akcji) przewyższają znacznie ich rzeczywistą, wewnętrzną wartość (Speculative Bubble...). Oczywiście powstaje tu problem z możliwością wyznaczenia wartości wewnętrznej. Istnieją dwa główne podejścia do tej kwestii. Pierwsze - racjonalne - zakłada, że ceny akcji wyznaczane są na podstawie wartości spółki, a ta obliczana jest w oparciu o szacunki przyszłych nadwyżek finansowych. Drugie utrzymuje, że wartość wewnętrzna w ogóle nie istnieje, a ceny akcji są wyznaczane w wyniku gry popytu i podaży. Ogólnie ujmując, bańka powstaje, gdy oczekiwania inwestorów dotyczące korzyści finansowych znacznie przekraczają możliwości generowania takich korzyści przez spółkę czy grupę spółek. Zamiennie z określeniem „bańka spekulacyjna” używa się terminów „bańka finansowa”, „bańka cenowa”, „mania spekulacyjna”, „gorączka spekulacyjna" $\mathrm{i}$ in.

Bańka na brytyjskim rynku nieruchomości pojawiła się i zaczęła rozwijać wraz $\mathrm{z}$ bańką spekulacyjną na giełdzie w połowie lat 90. Logika rządząca rozrastaniem się bańki spekulacyjnej jest niezwykle prosta. Osoby, których bogactwo zwiększyło się znacząco dzięki niezwykłemu wzrostowi cen akcji, mogły wydawać pieniądze i konsumować. To zaś doprowadziło do boomu konsumpcyjnego końca lat 90., w efekcie czego stopa oszczędności spadła z poziomu niemal $5 \% \mathrm{w}$ połowie dekady do nieco ponad $2 \%$ w 2000 roku.

Powstałe na giełdach bogactwo napedzało boom konsumpcyjny i zachęcało ludzi do kupowania większych lub lepszych domów - Brytyjczycy chcieli wydać część swojego bogactwa na nieruchomości. Ten wzrost popytu zaowocował powstaniem bańki spekulacyjnej, ponieważ w krótkiej perspektywie podaż domów jest względnie stała. Dlatego też wzrost popytu na nieruchomości powoduje w pierwszej kolejności wzrost cen. Kiedy więc ceny zaczeły rosnąć w miejscach, gdzie wzrost popytu był największy, dalsza aprecjacja cen została uwzględniona w oczekiwaniach. Oczekiwania co do dalszego wzrostu cen nieruchomości doprowadziły do sytuacji, w której osoby decydujace sie na zakup domu płaciły za nieznacznie więcej niż w normalnych warunkach. W ten sposób oczekiwania stały się samospełniającą się przepowiednią.

\section{Skutki kryzysu finansowego w ujęciu makroekonomicznym}

Światowy kryzys gospodarczy nie tylko wpłynął negatywnie na uczestników rynku finansowego, lecz także odcisnął swoje piętno na funkcjonowaniu całej gospodarki Wielkiej Brytanii. Pojawiające się zjawiska kryzysowe na rynku finansowym w Wielkiej Brytanii spowodowały spowolnienie gospodarcze. Kryzys finansowy negatywnie wpłynął na Produkt Krajowy Brutto poprzez jego następujące części składowe: inwestycje, konsumpcję, wydatki rządowe oraz eksport netto.

Dynamiczny rozwój nieruchomości w Wielkiej Brytanii możliwy był dzięki wzrastającemu Produktowi Krajowemu Brutto (PKB), który utrzymywał się na dodatnim poziomie, sięgając w latach 2001-2007 odpowiednio od 3,1-3,5\% (tab. 1), inflacji poniżej $3 \%$ oraz niskim stopom procentowym (do 5\% przed 2007 rokiem), które stały się dobra sposobnościa do rozwoju rynku nieruchomości i powstawania bańki spekulacyjnej na rynku.

\subsection{Inwestycje}

Inwestycje są ważną częścią PKB. Ograniczenia w dostępie firm do źródeł finansowania ich działalności, a także rosnący koszt tego finansowania osłabiają średnio- i długoterminowy rozwój gospodarczy firmy. Skutkiem kryzysu gospodarczego były trudności ze zdobyciem kapitału zarówno przez zaciąganie kredytu bankowego, jak i emisji papierów wartościowych. Wiele firm miało problemy ze sprzedażą dóbr, co powodowało brak pieniędzy na realizację inwestycji. Również zbyt wiele

Tabela 1. Dynamika PKB w Wielkiej Brytanii w latach 2001-2012

\begin{tabular}{|l|c|c|c|c|c|c|c|c|c|c|c|c|}
\hline Wskaźniki & $\mathbf{2 0 0 1}$ & $\mathbf{2 0 0 2}$ & $\mathbf{2 0 0 3}$ & $\mathbf{2 0 0 4}$ & $\mathbf{2 0 0 5}$ & $\mathbf{2 0 0 6}$ & $\mathbf{2 0 0 7}$ & $\mathbf{2 0 0 8}$ & $\mathbf{2 0 0 9}$ & $\mathbf{2 0 1 0}$ & $\mathbf{2 0 1 1}$ & $\mathbf{2 0 1 2}$ \\
\hline PKB $(\%)$ & 3,1 & 2,6 & 3,5 & 2,9 & 2,1 & 2,6 & 3,5 & $-1,1$ & $-4,4$ & 2,1 & 0,8 & 1,0 \\
\hline
\end{tabular}

Źródło: Dane MFW (2013).

Wydział Zarządzania UW ～DOI 10.7172/1733-9758.2013.16.6 
niewiadomych wynikających z recesji, trudnych do umieszczenia $\mathrm{w}$ biznesplanach, powodowało, że działalność inwestycyjna stawała się bardzo ryzykowna.

Inwestycje w nieruchomości były jedną z najbardziej opłacalnych form inwestowania, ze względu na szybki zysk i pewność zwrotu poniesionych kosztów. Jednak dotyczyło to osób posiadających odpowiedni zasób kapitału lub dysponujących możliwościami jego pozyskania. Na rynku Wielkiej Brytanii w latach 2008-2013 zetknięto się niestety z problemami związanymi z ograniczeniem finansowania w nieruchomości.

Zmiana warunków ekonomicznych zarówno w skali kraju, jak i na gruncie międzynarodowym wymusiła ewolucję mechanizmów finansujących rynek nieruchomości. Łatwiejszy przepływ kapitałów oznacza wzrost możliwości finansowania inwestycji w nieruchomości, co długofalowo sprzyja rozwojowi lokalnych rynków nieruchomości. Analizując sytuację Wielkiej Brytanii, zauważono liczne czynniki ograniczające inwestycje w nieruchomości (Kowalak, 2009, s. 89).

Jak każdy rynek nieruchomości, również ten w Wielkiej Brytanii podlega wielu regulacjom, których niestabilność ostatnich lat wprowadziła element niepewności w działalności inwestorów. Interwencyjnego wpływu na rynek nie można jednak uniknąć, gdyż w większości przypadków jest on niezbędny.
Według wstępnych danych OECD, w 2012 r. poziom bezpośrednich inwestycji zagranicznych (BIZ) brytyjskich przedsiębiorstw wyniósł 71,8 mld USD (ok. 47,1 mld GBP), znacznie poniżej poziomu z 2011 r., gdy wyniósł on 106,7 mld USD (najwyższa wartość od momentu rozpoczęcia kryzysu gospodarczego w 2008 r.). Jak podaje z kolei brytyjski urząd statystyczny ONS, w całym 2011 r. nastąpiła znaczna poprawa w dynamice inwestycji brytyjskich w Europie i Ameryce, jednak największy wzrost brytyjskich BIZ nastąpił w krajach azjatyckich, co wskazuje na rosnące zainteresowanie inwestorów wschodzącymi rynkami Chin i Indii. Najwyższy poziom brytyjskich inwestycji odnotowuje się nadal w Stanach Zjednoczonych (nieprzerwanie od ponad dekady) oraz Holandii i Luksemburgu (Gospodarka brytyjska..., 2013).

Ponadto, według danych OECD, w 2012 r. zagraniczne przedsiębiorstwa zainwestowały w Wielkiej Brytanii 62,7 mld USD (ok. 41,1 mld GBP), co stanowi wzrost o 7,6 mld GBP w skali roku. Dzięki tak dobrym wynikom w zakresie BIZ, Wielka Brytania zajmuje czołową pozycję w globalnej tabeli państw OECD - drugie miejsce w Europie, a czwarte na świecie pod względem wartości zainwestowanego w tym państwie kapitału zagranicznego. Wstępne szacunki OECD potwierdzają też dane ONS dot. BIZ za 2011 r., zgodnie z którymi najwięcej inwestycji

Wykres 1. Czynniki ograniczające rozwój inwestycji w nieruchomości w Wielkiej Brytanii

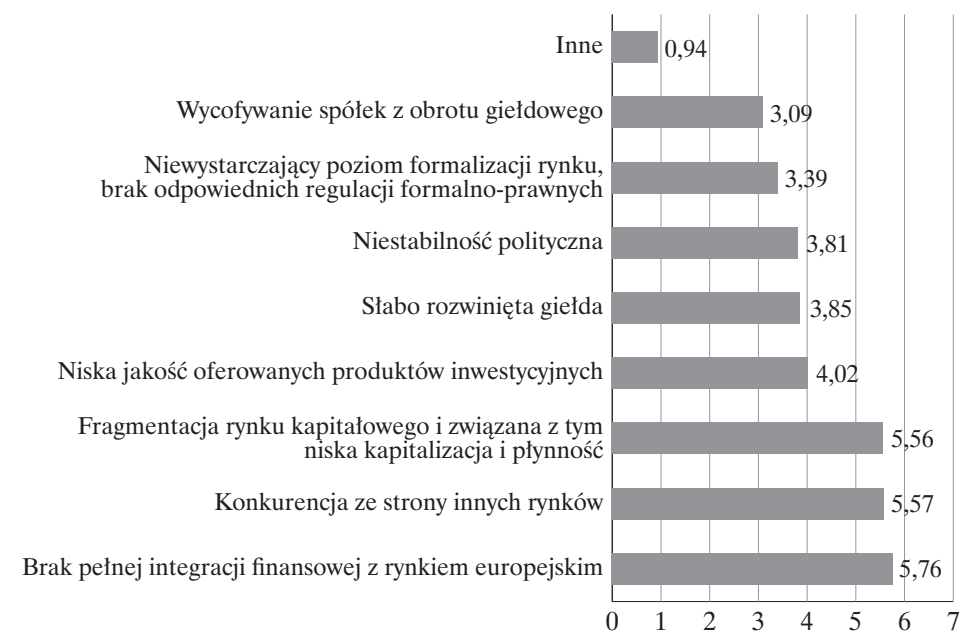

Źródło: House Price Index (HPI); Office for National Statistics: Newport (2012). 
Tabela 2. Nastroje konsumentów w Wielkiej Brytanii w latach 2001-2013

\begin{tabular}{|c|c|c|c|c|c|c|c|c|c|c|c|c|}
\hline Rok & $\mathbf{2 0 0 1}$ & $\mathbf{2 0 0 2}$ & $\mathbf{2 0 0 3}$ & $\mathbf{2 0 0 4}$ & $\mathbf{2 0 0 6}$ & $\mathbf{2 0 0 7}$ & $\mathbf{2 0 0 8}$ & $\mathbf{2 0 0 9}$ & $\mathbf{2 0 1 0}$ & $\mathbf{2 0 1 1}$ & $\mathbf{2 0 1 2}$ & $\mathbf{2 0 1 3}$ \\
\hline $\boldsymbol{\%}$ & 0,1 & 0,2 & $-5,0$ & $-5,0$ & $-8,0$ & $-8,0$ & $-15,0$ & $-38,0$ & $-19,0$ & $-29,0$ & $-31,0$ & $-22,0$ \\
\hline
\end{tabular}

Źródło: Dane statystyczne GUS.

pochodziło z krajów europejskich i obu Ameryk (po ok. 13-14 mld GBP). Według danych ONS, największym inwestorem zagranicznym w Wielkiej Brytanii były tradycyjnie Stany Zjednoczone, z inwestycjami na poziomie ponad 20 mld GBP. Drugim największym inwestorem jest Holandia, $\mathrm{z}$ inwestycjami na poziomie $12 \mathrm{mld}$ GBP (Gospodarka brytyjska..., 2013).

$\mathrm{Z}$ danych UK Trade and Investment (UKTI) wynikało, że w roku 2011 miała miejsce kontynuacja tendencji wzrostowej w odniesieniu do zagranicznych inwestycji bezpośrednich netto (BIZ) dokonywanych przez firmy brytyjskie; BIZ osiagnęły wówczas wartość 68,2 mld GBP, co oznacza poziom najwyższy od 2008 r. (np. w $2010 \mathrm{r}$. wyniosły one 25,5 mld GBP). Z kolei zagraniczne inwestycje w Wielkiej Brytanii systematycznie się kurczyły i ostatecznie ich wysokość osiągnęła kwotę 31,9 mld GBP na koniec 2011 r.

Jak podawał wówczas UKTI, łączna kwota brytyjskich BIZ w 2011 r. była zróżnicowana z punktu widzenia geograficznego ich lokowania. Firmy brytyjskie najwięcej zainwestowały $\mathrm{w}$ Europie 30,9 mld GBP (11,4 mld GBP w 2010 r., najwyższy wzrost od 2008 r.), a zwłaszcza w Luksemburgu (8 mld GBP) oraz w Belgii (5,6 mld GBP). Odnotowano także wzrost BIZ w Azji (0,8 mld GBP) oraz obu Amerykach (19,0 mld GBP); natomiast spadek - w Australii i Oceanii (z 11,7 mld GBP w 2010 r. do 0,9 mld GBP w 2011 r.), co było spowodowane przede wszystkim redukcją zadłużenia firm brytyjskich w stosunku do ich zagranicznych spółek. W tym samym roku, najwięcej zainwestowały w Wielkiej Brytanii kolejno: kraje obu Ameryk - łącznie 14,3 mld GBP, Europy - 13,2 mld GBP oraz Azji - 3,0 mld GBP (Gospodarka brytyjska..., 2013).

\subsection{Konsumpcja}

Słabnące na skutek kryzysu gospodarczego wyniki działalności przedsiębiorstw szybko wpływają na rynek pracy, szczególnie w Wielkiej Brytanii, gdzie jest on bardziej elastyczny. Stopa bezrobocia w III kwar- tale 2008 wzrosła do 5,8\% w porównaniu z poziomem 5,4 w II kwartale 2008 r. Liczba bezrobotnych wzrosła do 36,5 tys. osób i był to największy wzrost od 1992 roku. Tabela 2 ukazuje nastroje konsumentów, jakie odnotowano w latach 2001-2012.

Jak wskazują dane statystyczne konsumpcja spadała od 2002 roku, osiągając swoje maksimum w roku 2009. W kolejnych latach uległa natomiast poprawie, jednak wyniki dalekie są od ideału. Pogarszające się warunki ekonomiczne wpłynęły negatywnie na nastroje wśród konsumentów, od których zależy skłonność gospodarstw domowych do konsumpcji.

$\mathrm{Na}$ Wyspach wydatki na produkty społeczne i ekologiczne stale rosną, nawet w czasach kryzysu ekonomicznego. Co więcej, już ponad połowa Brytyjczyków deklaruje, że dokonała wyboru konsumenckiego w oparciu o społeczną reputacje firmy, a połowa - że zrezygnowała z jakiegoś zakupu ze względu na aspekty społeczne czy ekologiczne. Ok. $78 \%$ regularnie kupuje w lokalnych sklepach i od lokalnych dostawców (ECRA, 2012).

Rynek dóbr luksusowych w Wielkiej Brytanii był napędzany wzrostem gospodarczym oraz rosnącą liczbą dobrze sytuowanych gospodarstw domowych. Jednak pomimo kryzysu gospodarczego jego perspektywy są dobre. Stały wzrost realnych dochodów do dyspozycji w latach 2011-2020 podniesie wydatki konsumentów, co dobrze rokuje całej branży dóbr luksusowych. Wzrost rynku dóbr luksusowych będzie najbardziej widoczny w największych miastach.

Przed kryzysem rynki europejskie notowały w zasadzie nieprzerwany wzrost wartości udzielanych kredytów konsumenckich. Był on spowodowany bezpośrednim następstwem rozwoju gospodarczego, wzrostu PKB krajów członkowskich oraz rosnącym popytem na dobra i usługi konsumenckie - popytem, którego konsumenci nie są w stanie zaspokoić w całości ze zgromadzonych oszczędności.

Według danych za 2008 r., czyli datowanych przed wybuchem recesji, najwięk- 
szym rynkiem kredytów konsumenckich w Europie była Wielka Brytania. Sytuacja ta zaczęła się zmieniać po tym roku, w momencie gdy instytucje finansowe ograniczyły podaż kredytów, a konsumenci, w obawie przed niepewną sytuacją, przestali te kredyty zaciągać. Zaczął wzrastać wskaźnik upadłości konsumenckiej. W Wielkiej Brytanii co godzinę oddłuża się średnio nawet 200 osób - to prawie siedem razy więcej niż w Polsce w ciągu roku (Upadtość konsumencka..., 2012).

Dostępność upadłości konsumenckiej wzrosła po przejęciu władzy przez Partię Pracy w 1997 r. Na efekty nie trzeba było długo czekać. Wielu konsumentów doszło do wniosku, że bardziej opłaca się ogłaszać bankructwo, niż spłacać zaciągnięte kredyty. Liczba nadużyć stale wzrasta, podobnie jak liczba bankructw osób prywatnych. Jeszcze w 2002 r. problem dotyczył niecałych 34 tys., a w 2006 r. już prawie 117 tys. osób (Creditreform..., 2010). Oznacza to 3,5-krotny wzrost $\mathrm{w}$ ciagu zaledwie 4 lat. W 2012 r. miesięcznie upadłość ogłaszało około 20000 konsumentów. Podobna liczba upadłości konsumenckiej jest odnotowywana w roku 2013.

Brytyjski nadzór finansowy szacuje, że problemy ze spłatą własnych długów może mieć aż 3 miliony Brytyjczyków. Dla porównania w Niemczech również odnotowuje się trend wzrostowy, ale nie aż tak drastyczny, jak na Wyspach. Oznacza to znaczne pogorszenie wyników finansowych banków. Bank Barclays, czołowy brytyjski bank detaliczny, w 2006 r. musial przeznaczyć aż 2,1 mld funtów na odpisy na tzw. złe długi. $\mathrm{Z}$ kolei HSBC, jeden $\mathrm{z}$ największych brytyjskich banków, zapowiedział, że będzie zmuszony wprowadzić pobieranie opłat za prowadzenie rachunków bieżących, które do tej pory były usługą darmową, aby w ten sposób ciężar kosztów generowanych przez niespłacających mógł zostać przeniesiony na klientów posiadających rachunki indywidualne. Sytuacja w innych wiodących bankach jest podobna. W całym kraju szacuje się, że zagrożonych może być 1,2 bln funtów na kartach kredytowych, w kredytach konsumpcyjnych, pożyczkach i hipotekach (Creditreform..., 2010).

Negatywnym zjawiskiem w Wielkiej Brytanii jest powstawanie doradców upadłościowych, którzy zachęcają do upadłości jako łatwego sposobu na ucieczkę od długów, przy czym nieźle na tym zarabiają kosztem brytyjskich banków. Pod wpływem kryzysu nastąpiła przemiana w sferze wartości. Dla starszych pokoleń Brytyjczyków spłata długów była sprawą oczywistą. W dobie kryzysu coraz bardziej akceptowalnym wyjściem z zadłużenia nie jest jego spłata, lecz ogłoszenie upadłości.

\subsection{Wydatki rządowe}

Wydatki rządowe, podobnie jak inwestycje oraz konsumpcja, wpływaja znaczaco na PKB. W Wielkiej Brytanii wydatki te rosły od wielu lat co było powodem do zadowolenia. Każdorazowe zwiększenie wydatków rządowych musi być sfinansowane w drodze podniesienia dochodów poprzez zwiększenie podatków, podniesienie długu publicznego. Pieniądze na finansowanie wydatków rządowych można osiągać poprzez zaciąganie przez państwo kredytów w kraju lub za granicą lub emisję obligacji skarbowych i bonów skarbowych na rynku krajowym lub zagranicznym. Każda forma zadłużenia wiąże się z kosztem jego obsługi w formie oprocentowania oraz zwrotu pożyczonego kapitału. Wzrost długu publicznego negatywnie wpływa na konsumpcję oraz inwestycje poprzez efekt wypychania i dlatego osłabia długoterminowy rozwój kraju. Wzrost długu wpływa na gospodarstwa domowe, ponieważ w przyszłości zapewne zostaną podniesione podatki w celu spłaty długu i w konsekwencji nastapi spadek dochodu do dyspozycji oraz w przypadku przedsiębiorstw poprzez zmniejszenie możliwości finansowania inwestycji.

Analizujac wielkość długu publicznego, można zauważyć, że od 2001 roku kształtował się on na poziomie $41-43 \%$, aż do 2008 roku, kiedy Wielką Brytanię ogarnął kryzys finansowy. W tym roku dług publiczny osiagnał wielkość 44,5\% i wzrastał aż do 86,4\% w 2012 roku. Najnowsze dane sugerują, iż gospodarka brytyjska jest, mimo wszelkich starań, dalsza od przywrócenia równowagi niż szacowano poprzednio. Wykres 2 przedstawia kształtowanie się długu publicznego w latach 2001-2013 w Wielkiej Brytanii.

Kryzys finansowy spowodował uruchomienie działań interwencyjnych w Wielkiej Brytanii. Działania te nie były przewidziane w budżecie państwa i w przyszłości będą musiały być sfinansowane poprzez kredyt lub emisję papierów wartościowych. Szczególnie istotne jest zatem w obliczu kryzysu zapewnienie przez państwo - z czym wiąże się wzrost wydatków rządowych - stabil- 
Wykres 2. Dług publiczny w Wielkiej Brytanii w latach 2001-2013

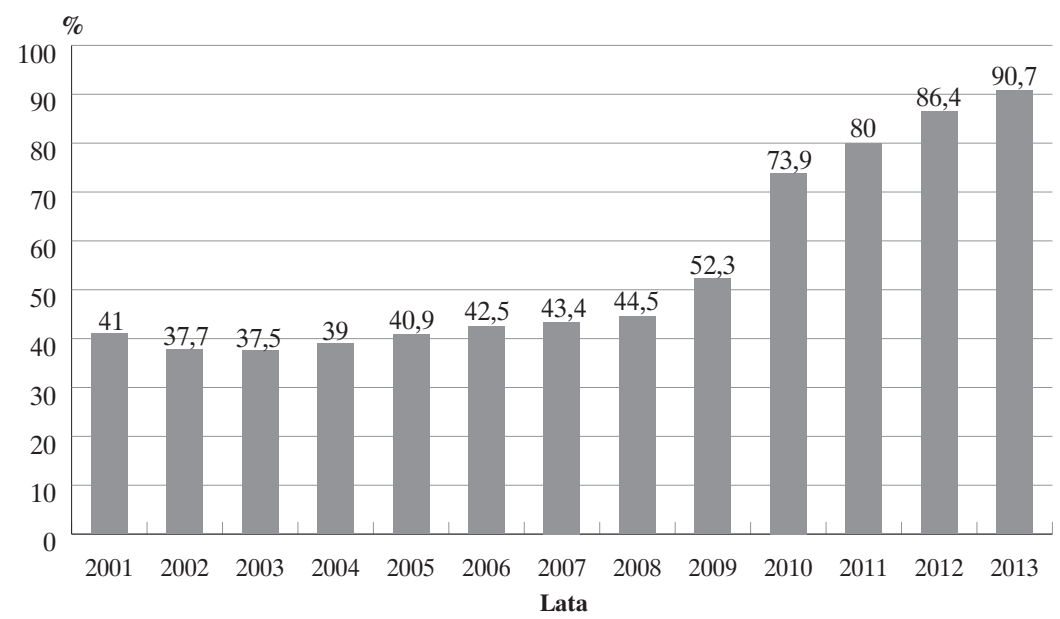

Źródło. Eurostat.

nego wzrostu gospodarczego, mimo trudności odpowiedniego wykorzystania posiadanych zasobów, powrotu do stabilności cen, przywrócenia równowagi bilansu płatniczego, poprawy poziomu technologicznego i w efekcie podniesienia wydajności krajowych przedsiębiorstw, zapewnienia i przywrócenia właściwego poziomu kontroli nad systemem gospodarki krajowej, społecznej stabilności i poprawy jakości życia obywateli. W tym kontekście efektywne wykorzystanie przez państwo działalności przedsiębiorstw i możliwości konsumpcyjnych obywateli, poprzez powiększanie zasobów kapitału może przyczynić się do podniesienia jego bezpieczeństwa ekonomicznego i umocnienia pozycji gospodarczej (Woźniak, 2011).

Kryzys finansowy 2008-2009 postawił poważne wyzwania przed polityką makroekonomiczna, w tym fiskalną. Działania interwencjonistyczne Wielkiej Brytanii, obejmujące m.in. pakiety antykryzysowe, skutkują podobnie, tzn. zwiększają wydatki państwowe, np. inwestycyjne i/lub socjalne oraz, poprzez obniżki podatków mających na celu pobudzenie popytu, obniżają dochody budżetowe. Efektem powyższych zjawisk jest pogorszenie stanu finansów publicznych początkowo w obrębie deficytu budżetowego, a następnie w zakresie długu publicznego. Wszystkie czynniki makroekonomiczne wywarły znaczny wpływ na rynek nieruchomości i aspekty rynku z nim powiązane, jak koszty kredytu, oprocentowanie, ceny nieruchomości i popyt na rynku.

Dane zawarte w tabeli 3 ukazują sytuacje gospodarcza od roku 2001 i niekorzystne zmiany w gospodarce. Mała nadwyżka budżetowa miała miejsce $\mathrm{w}$ jedynie w roku 2001. Następnie od 2002 roku nastapił stabilny wzrost wydatków budżetowych nad wpływami. I taka sytuacja utrzymywała sie aż do 2008 roku. Gospodarka Wielkiej Brytanii wygenerowała większą przewagę wydatków w budżecie w 2009 r. Wydatki w okresie kryzysu urosły trzykrotnie. Wielka Brytania mimo wszystko stymulowała w tym czasie gospodarkę do odwrócenia skutków kryzysu.

W omawianym okresie Wielka Brytania jedynie w latach 2001-2009 nie miała najmniejszych trudności z ustabilizowaniem długu poniżej granicy $60 \%$ PKB, jednakże

Tabela 3. Deficyt budżetowy (\% PKB)

\begin{tabular}{|c|c|c|c|c|c|c|c|c|c|c|c|c|}
\hline \multicolumn{1}{|c|}{ Wskaźnik } & $\mathbf{2 0 0 1}$ & $\mathbf{2 0 0 2}$ & $\mathbf{2 0 0 3}$ & $\mathbf{2 0 0 4}$ & $\mathbf{2 0 0 5}$ & $\mathbf{2 0 0 6}$ & $\mathbf{2 0 0 7}$ & $\mathbf{2 0 0 8}$ & $\mathbf{2 0 0 9}$ & $\mathbf{2 0 1 0}$ & $\mathbf{2 0 1 1}$ & $\mathbf{2 0 1 2}$ \\
\hline $\begin{array}{l}\text { Deficyt budżetowy } \\
\text { (\% PKB) }\end{array}$ & 3,6 & 0,5 & $-2,1$ & $-3,4$ & $-3,4$ & $-3,4$ & $-2,7$ & $-2,7$ & $-11,4$ & $-10,4$ & $-8,6$ & $-7,0$ \\
\hline
\end{tabular}

Źródło: dane statystyczne GUS. 
od 2002 r. obserwuje się tendencję do jego stopniowego zwiększania. Natomiast lata 2010-2013 to zdecydowanie przekroczenie tego pułapu. Wielka Brytania od roku 2008 ma jeden z najwyższych, spośród wszystkich unijnych krajów, deficyt budżetów, znacznie przekraczajacy średnią strefy euro (1,0\% PKB w 2008 r. i 1,1\% w 2009 r.). Natomiast w przypadku długu publicznego sytuacja również jest nie najlepsza, ponieważ nastąpiło pogorszenie od momentu kryzysu finansowego. Wpływ na to miało zmniejszenie się wpływów do budżetu brytyjskiego, związanego $\mathrm{z}$ pogorszeniem wyników na rynku aktywów i nieruchomości, a także redukcji strumienia dochodów z podatków pośrednich. Recesja zmusiła rząd do zdecydowanych działań, w celu zminimalizowania negatywnych efektów ekonomicznych i społecznych kryzysu oraz niedopuszczenia do depresji gospodarczej na wzór lat 30 . XX w.

Działania rządu brytyjskiego $\mathrm{z}$ jednej strony wzmocniły sektor finansowy, $\mathrm{z}$ drugiej zaś - pomoc dla sektora finansowego ma niekorzystny wpływ na stan finansów publicznych, które i tak, z powodu znacznie zredukowanej aktywności gospodarczej, uległy pogorszeniu.

Obecnie szacuje się, że w 2013 roku tempo wzrostu PKB wyniesie tylko $1,2 \%$, a w 2014 roku - 2\%. Jest to znaczna obniżka poprzednich prognoz. Wielu analityków uważa, że nastąpi korzystny rozwój gospodarczy w średniej perspektywie czasowej, twierdząc, że od 2015 roku należy się spodziewać powrotu do tempa wzrostu PKB wynoszącego 2,5-3 proc. rocznie, chociaż akurat na ten okres zaplanowano najpoważniejsze cięcia budżetowe. Jednak na podstawie dotychczasowego doświadczenia można się spodziewać, że wspomniane prognozy będą obniżane w miarę, jak będziemy zbliżać się do tego okresu. Zakłada się, iż nieco większa część deficytu zostanie zlikwidowana poprzez ożywienie gospodarcze i nie będą konieczne dalsze drastyczne cięcia mające na celu zmniejszenie deficytu budżetowego.
Przewidywany „deficyt strukturalny” to deficyt budżetowy skorygowany o wahania cykliczne. Hipotetyczny deficyt, który wystąpiłby, gdyby nie było zjawisk tworzacych cykl koniunkturalny (Nbportal.pl, 2013), nadal pozostaje bardzo duży. Na domiar złego Minister Finansów ogłosił, że program cięć budżetowych zostanie wydłużony o rok, czyli potrwa do roku 2017/2018. Perspektywy rozwoju gospodarki brytyjskiej w najbliższej przyszłości, jak i dłuższej perspektywie są bardzo słabe.

Dlatego też Minister Finansów, George Osborne, zakłada, że realizacja ogłoszonego celu budżetowego rządu, którym jest likwidacja obecnego deficytu strukturalnego potrwa osiem lat. Nie uda mu się również osiągnąć kolejnego $\mathrm{z}$ podstawowych celów polityki budżetowej, czyli nie doprowadzi do zmniejszenia stosunku zadłużenia publicznego do PKB w roku fiskalnym 2015/2016. Ma to nastąpić dopiero w roku następnym.

\subsection{Eksport netto}

Bilans handlu zagranicznego to nic innego, jak nadwyżka eksportu nad importem. Aktywność gospodarcza Wielkiej Brytanii uzależniona jest od wielu czynników, do których zaliczyć można popyt na dobra i usługi. W czasie kryzysu takie inwestycje, jak konsumpcja maleją, co negatywnie wpływa na obrót handlu zagranicznego, który jak wszystkie czynniki odzwierciedla sytuację gospodarczą i zmiany w bilansie handlowym. W ostatnich latach, jak ukazują dane statystyczne, funkcjonował on w warunkach poważnych zawirowań koniunkturalnych. Tabela 4 ukazuje zmiany w bilansie handlowym w latach 2001-2013.

Niekorzystne zmiany w bilansie handlowym obserwowane są od 2006 roku, uległy one poprawie w 2009 roku i tu nastąpiło kolejne załamanie. Mimo niewielkiego ożywienia przebiegającego w zróżnicowanym tempie, w drugim półroczu 2011 roku zaobserwowano słabości finansów publicznych i systemu bankowego.

Tabela 4. Bilans handlowy Wielkiej Brytanii w latach 2001-2013 (w mln GBP)

\begin{tabular}{|c|c|c|c|c|c|c|c|c|c|c|c|c|}
\hline \multicolumn{10}{|c|}{ Rok } \\
\hline $\mathbf{2 0 0 1}$ & $\mathbf{2 0 0 2}$ & $\mathbf{2 0 0 3}$ & $\mathbf{2 0 0 4}$ & $\mathbf{2 0 0 5}$ & $\mathbf{2 0 0 6}$ & $\mathbf{2 0 0 7}$ & $\mathbf{2 0 0 8}$ & $\mathbf{2 0 0 9}$ & $\mathbf{2 0 1 0}$ & $\mathbf{2 0 1 1}$ & $\mathbf{2 0 1 2}$ & $\mathbf{2 0 1 3}$ \\
\hline-55000 & -140000 & -110000 & -57000 & -152000 & -180000 & -240000 & -235000 & 70000 & -180000 & -125000 & 10000 & -40000 \\
\hline
\end{tabular}

Źródło: dane statystyczne GUS 
Zgodnie $\mathrm{z}$ danymi HM Revenue \& Customs w okresie styczeń-maj 2013 r. łączna wartość brytyjskich obrotów handlowych ze światem wyniosła 231,9 mld GBP, przy czym ujemne dla Wielkiej Brytanii saldo wyniosło 35,8 mld GBP. W pierwszym kwartale 2013 r. wartość zarówno importu, jak i eksportu spadła nieznacznie w stosunku do czwartego kwartału 2012 r. (odpowiednio o 2,3 i 2,1\%). W porównaniu z kwietniem 2012 r. nastąpiła też niewielka redystrybucja salda handlu na rzecz krajów UE kosztem państw spoza EOG, spowodowana głównie zmniejszeniem się rekordowo wysokiego deficytu eksportowego z krajami UE (z 6,1 mld GBP w 04.2012 r. do 5,2 mld GBP w 04.2013 r.).

Zgodnie $\mathrm{z}$ raportem miesięcznym HM Revenue \& Customs, od początku roku do maja 2013 r. na obszarze Unii Europejskiej największymi eksporterami do Wielkiej Brytanii były kolejno: Niemcy, Holandia, Francja, Belgia i Włochy. W odniesieniu do brytyjskiego eksportu zauważalny jest znaczny spadek jego wartości w przypadku Holandii, kosztem zwiększonego wolumenu eksportu do Francji i Belgii (Gospodarka brytyjska..., 2013).

\section{Dzialania antykryzysowe w Wielkiej Brytanii}

Globalny kryzys finansowy wpłynął negatywnie na segmenty rynku finansowego oraz realną gospodarkę i spowodował uruchomienie skoordynowanej, wielomiliardowej pomocy rządowej w Wielkiej Brytanii. Wartość pomocy publicznej dla rynków była najwyższa, jeśli chodzi o procent PKB oraz wartość nominalną. Dla ratowania sektora bankowego konieczne było wyeliminowania ryzyka niewypłacalności banków na skutek braku możliwości sfinansowania zadłużenia na rynku międzybankowym, zmniejszenie ryzyka wycofania depozytów przez klientów. W tym celu wprowadzono2:

- gwarancje spłaty zobowiązań banków dla nowych krótko- i średnioterminowych zobowiazań banków o wartości 250 mld GBP, utrzymano w rezerwie kolejne 100 mld GBP na zamianę niepłynnych aktywów banku na papiery wartościowe Skarbu Państwa;

- system gwarantowania depozytów, podniesienie progu gwarancji rządowych dla depozytów z 35 tys. do 50 tys. GBP;

- ograniczenia w tzw. krótkiej sprzedaży, która została ograniczona do 16 stycznia
2009 roku i obejmowała akcje 34 podmiotów gospodarczych.

Interwencję rządowe miały na celu ustabilizowanie segmentu finansowego w średnim terminie, dlatego też państwo dokapitalizowało banki oraz obniżyło stopy procentowe, aby pobudzić rynek kredytowy i zmniejszyć koszty obsługi zadłużenia.

Plan ratunkowy w Wielkiej Brytanii na początku kryzysu wyceniono na prawie 700 mld USD

Jednak z biegiem lat okazało się, że działania antykryzysowe nie przyniosły oczekiwanych rezultatów. $\mathrm{Na}$ podstawie pesymistycznych prognoz wzrostu gospodarczego i gorszych perspektyw w kwestii zadłużenia publicznego Minister Finansów ogłosił umiarkowany program prowadzący do zwiększenia wpływów do budżetu, którego główne założenia są następujące:

- z 50 tys. funtów (80 tys. dol.) do 40 tys. funtów zmniejszono maksymalną roczną kwotę składek na ubezpieczenie emerytalne, umożliwiającą ulgę podatkowa; dotknie to zarabiających najwięcej; jednocześnie zredukowano limit składek odprowadzanych przez cały okres działalności zawodowej z 1,5 do 1,25 mln funtów; powinno to zapewnić około 1 mld funtów rocznie;

- budżety ministerstw zostaną dodatkowo zmniejszone o 1\% w 2013 roku i o 2\% w roku 2014; ponadto w kontrowersyjnym posunięciu Minister Finansów zdecydował sie na wieccej niż sie spodziewano i ogłosił dalsze redukcje świadczeń, co odczują gospodarstwa domowe osiągające niskie dochody; niemal wszystkie świadczenia, poza emeryturami, będa teraz przez trzy lata wzrastać nominalnie zaledwie o $1 \%$ rocznie; oznacza to znaczny spadek ich realnej wielkości, gdyż przewiduje się stopę inflacji wynoszącą około 3\%. Rocznie; zakłada się, że uzyskane dzięki temu oszczędności wyniosą około 1,2 mld funtów rocznie;

- zrezygnowano $\mathrm{z}$ planowanej podwyżki akcyzy nakładanej na paliwa, a do tego Minister Finansów zapowiedział umiarkowany wzrost kwoty dochodu wolnej od podatku oraz dodatkowe zmniejszenie o punkt procentowy stawki podatku dochodowego odprowadzanego przez przedsiębiorstwa; od kwietnia 2014 roku stawka tego podatku będzie wynosić $21 \%$; planowane zmiany stawek podatkowych i świadczeń oznaczają, że jedni 
na tym zyskają, inni stracą, ale George Osborne potwierdził, że owe różnorodne programy brane łącznie nie wpłyną zasadniczo na wielkość wpływów do budżetu państwa;

- Minister Finansów podał także więcej szczegółów dotyczacych nowych rozporządzeń określanych skrótem GAAR (General Anti-Abuse Rule), których celem jest przeciwdziałanie unikaniu podatków przez przedsiębiorstwa; rząd zdecydował się na te działania wskutek gniewnych reakcji społeczeństwa na informacje, że olbrzymie przedsiębiorstwa, takie jak Amazon czy Google, które osiagają ogromne obroty w Wielkiej Brytanii, odprowadzają bardzo małe kwoty tytułem podatku dochodowego od przedsiębiorstw albo tego podatku nie płacą w ogóle;

- George Osborne zapowiedział pewien zbiór działań zmierzających do zwiększenia konkurencyjności i zapewnienia przynajmniej drobnego bodźca wywołujacego wzrost gospodarczy; obniżenie realnej wielkości świadczeń w połączeniu z dalszymi cięciami budżetów ministerstw pozwoli przeznaczyć dodatkowe 5 mld funtów na inwestycje w infrastruktury szkolnictwa, nauki i transportu; trzeba tu dodać, że ogólny budżet inwestycji publicznych i tak jest radykalnie zmniejszany od 2010 roku;

- Minister Finansów powtórzył złożoną wcześniej obietnicę, że zapewni gwarancje państwowe prywatnym inwestycjom w infrastrukturę w wysokości $40 \mathrm{mld}$ funtów, nie wymienił jednak żadnych konkretnych przedsięwzięć, które miałyby być objęte tym programem; dziesięciokrotnie ponadto zostanie zwiększona roczna ulga podatkowa $\mathrm{z}$ tytułu inwestycji w zakłady produkcyjne i maszyny (do 250 tys. funtów), utworzona zostanie agencja wspierania eksportu dysponująca budżetem w wysokości 1,5 mld funtów, która ma pomagać małym i średnim przedsiębiorstwom w rozwijaniu działalności na zagranicznych rynkach;

- rząd ustanowi bank handlowy, którego zadaniem będzie zapewnianie prywatnego kapitału firmom niemogącym uzyskać dostepu do oferowanego przez banki komercyjne finansowania przy konkurencyjnych stawkach oprocentowania;

- Minister Finansów poinformował, że na początku przyszłego roku rząd zapowie reformę kontrowersyjnej inicjatywy finansowania prywatnego; system ten był powszechnie stosowany przez poprzedni rząd $w$ celu zapewnienia finansowania publicznych projektów infrastrukturalnych $\mathrm{z}$ wykorzystaniem kapitału prywatnego; jednakże w ostatnich latach Krajowe Biuro Audytorskie (National Audit Office, NAO) wyrażało poważne zaniepokojenie wysokim kosztem kapitału (a tym samym konsekwencjami ponoszonymi przez podatników) wykorzystywanego do realizacji takich przedsięwzięć, a także tym, że tych wydatków w większości nie uwzględniano w bilansach budżetu państwowego, pomimo zapewnienia gwarancji Skarbu Państwa.

- George Osborne ogłosił ulgi podatkowe dla przedsiębiorstw inwestujących w wydobycie gazu łupkowego i umożliwił budowę trzydziestu elektrowni gazowych ${ }^{3}$.

\section{Podsumowanie}

Kryzys finansowy negatywnie wpłynął na gospodarkę realną Wielkiej Brytanii. Ograniczył możliwości konsumpcyjne gospodarstw domowych oraz nastroje konsumentów, powodując spadek konsumpcji, która w Wielkiej Brytanii jest ważnym elementem PKB. Przedsiębiorstwa ograniczyły swoje możliwości inwestycyjne na skutek wzrostu kosztu pozyskania kapitału spowodowanego krachem na rynku papierów wartościowych oraz ograniczeniem akcji kredytowej przez banki. Kolejnym komponentem PKB, które zmniejszyło dochody państwa, było osłabienie handlu zagranicznego. Wszystkie te czynniki wprowadziły Wielką Brytania w fazę recesji, ograniczając aktywność ekonomiczną. Rząd brytyjski oraz Bank Centralny, chcąc ratować gospodarkę państwa, ogłosiły programy stymulujące wzrost gospodarczy liczony w setkach miliardów dolarów.

Na stan gospodarki Wielkiej Brytanii, jak wykazują analizy, wpłynęła potrzeba redukcji deficytów finansów publicznych w poszczególnych rynkach strefy euro, jak również silna awersja do ryzyka na rynkach finansowych, przy utrzymującej się niepewności co do sytuacji na rynku światowym, która przełożyła się na wyhamowanie realnej gospodarki. Wszelkiego rodzaju zjawiska towarzyszące procesom gospodarczym sa złożone i dobra koniunktura oraz wzrost gospodarczy zależy od wielu czynników wewnętrznych, ale i od sytuacji na rynkach światowych (Kaźmierczak, 2008). 
Decyzje Ministra Finansów nie zawierały specjalnych niespodzianek. Uważa on, że wzrost gospodarczy w Wielkiej Brytanii wymaga wielu poświęceń. Swiadczy to, że rząd od momentu przejęcia władzy nie poczynił konkretnych i trwałych postępów mających na celu zmniejszenie deficytu budżetowego.

Zmniejszanie wydatków inwestycyjnych oraz podwyżki podatków, czyli działania, które przynoszą skutki w krótkim terminie, zapewniły większość korzyści budżetowych uzyskanych do tej pory przy realizacji programu dostosowania. Dobrą wiadomością jest fakt, że deficyt budżetowy zmalał z 11,2\%. PKB w 2009 roku do mniej więcej $8 \%$ obecnie. Jednak rząd musi rozwiązać znacznie poważniejszy problem redukcji bieżących wydatków, aby deficyt został zmniejszony.

Bardzo dobrze postrzegane są przez podmioty gospodarcze decyzje Ministra Finansów służące złagodzeniu ograniczeń finansowych, które napotykają przedsiębiorstwa i gospodarstwa domowe, a także umiarkowany wzrost wydatków inwestycyjnych na programy infrastrukturalne.

Jednak tym co najbardziej martwi firmy produkujące jest niepewna przyszłość, jeśli chodzi o popyt na ich produkty. Przedsiębiorstwa będą decydować się na inwestycje, jeśli nie będą miały pewności, że na ich produkty będzie dostateczne zapotrzebowanie. Panuje ogólny pogląd, że rząd nie zamierza nic robić w celu pobudzania popytu.

\section{Przypisy}

1 Opracowanie własne na podstawie modelu Minsky'ego.

2 Opracowanie własne na podstawie danych z Financial Times (2008).

3 Londyn tnie deficyt, gdy problemem jest brak popytu, Obserwator finansowy.pl 2013

\section{Bibliografia}

Bank of England (2012). Quarterly Bulletin, Q1, 52(1), 50-51.

Bryx, M. (2008). Rynek nieruchomości system i funkcjonowanie. Warszawa: Poltekst.

Döhle, P. i Hage, S. (2008). Tajemnica baniek spekulacyjnych, Manager Magazine.

ECRA (2012). Ethical Consumerism Report 2010 Pobrano z: http://www.goodwithmoney.co.uk/ethicalconsumerismre.
Financial Times (2008).

Gadomski, W. (2009). Chmury bardzo czarne, Manager, 1(50), 55.

Gospodarka brytyjska (2013). Londyn: Ambasada Rzeczypospolitej Polskiej w Londynie.

Jajuga, K. i Cegielski, P. (2003). Stopa dyskontowa w wycenie nieruchomości podejściem dochodowym, cz. I - stopa procentowa, stopa zwrotu, stopa dyskontowa - podstawy teoretyczne, Nieruchomości, 9(61), wrzesień.

Jurek, M. (2008). Lekarstwo na ekonomiczną depresję, Rynki zagraniczne, 46-47(7672), 21.

Kaźmierczak, A. (2008). Podstawy polityki pieniężnej. Warszawa: WN PWN.

Kindleberger, Ch. (1999). Szaleństwo, panika, krach. Warszawa: WIG Press.

Kosiński, A. (1997). Sekurytyzacja aktywów na świecie $i$ w Polsce, Warszawa: Biblioteka Menedżera i Bankowca.

Kowalak, T. (2009). Integracja rynków kapitatowych. Warszawa: Narodowy Bank Polski.

Kowalska, M.M. (2009). Polityka stabilizacyjna Wielkiej Brytanii w warunkach kryzysu i jej konsekwencje po roku 2012. W: S. Antkiewicz, M. Pronobis (red.), Gospodarka w warunkach kryzysu. Warszawa: CeDeWu.

Miles, D. (2011). Speech, Mortgages, housing and monetary policy - what lies ahead?, Bank of England, York Racecourse, 22 November 2011.

Nawrot, W. (2009). Globalny kryzys finansowy w XXI wieku. Przyczyny, przebieg, skutki, prognozy. Warszawa: CeDeWu.

Ofek, E. i Richardson, M. (2003). DotCom Mania: The Rise and Fall of Internet Stock Prices, Journal of Finance, June, 1113-1137.

Shiller, R.J. (2001). Irrational Exuberance. New Jersey: Princeton University Press.

Sławiński, A. (2006). Rynki finansowe. Warszawa: PWE.

Upadłość kosumencka - tylko na papierze (2012). Bankier.pl, wrzesień.

Woźniak, M.G. (2011). Wzrost gospodarczy. Podstawy teoretyczne. Kraków: AE w Krakowie.

\section{Strony internetowe}

Bank Anglii. Pobrano z: http://www.bankofengland. co.uk/.

Bank Światowy. Pobrano z: http://data.worldbank. org/country/united-kingdom.

Brown przyznaje: Wielkiej Brytanii grozi recesja. Pobrano z: http://www.tvn24.pl/biznes-gospodarka,6/brown-przyznaje-wielkiej-brytanii-grozirecesja,74404.html (22.10.2008).

Creditreform, Annual Reports, 2010. 
Druga kroplówka dla brytyjskich banków. Pobrano z: http://www.tvn24.pl/biznes-gospodarka,6/drugakroplowka-dla-brytyjskich-bankow,83016.html.

Eurostat. Pobrano z: http://epp.eurostat.ec.europa. $\mathrm{eu} / \mathrm{tgm} /$ table.do $?$ tab $=$ table $\&$ init $=1 \&$ language $=$ en $\&$ pcode $=$ tec $00115 \&$ plugin $=1$.

http://www.bankofengland.co.uk/publications/ Documents/quarterlybulletin/qb1201.pdf.

http://www.communities.gov.uk/housing/housingresearch/housingstatistics/housingstatisticsby/ housingmarket/livetables/.

http://www.communities.gov.uk/publications/housing/housingstrategy2011.

http://www.housepricecrash.co.uk/\#statistics.

http://www.lloydsbankinggroup.com/media1/economic_insight/halifax_house_price_index_page.asp.

http://www.ons.gov.uk/ons/publications/re-reference-tables.html? edition $=\mathrm{tcm} \% 3 \mathrm{~A} 77-242396$. http://www.tradingeconomics.com/united-kingdom/ inflation-cpi.

http://www.tradingeconomics.com/united-kingdom/ interest-rate.

http://www.tvn24.pl/biznes-gospodarka,6/niewyplacalny-jak-brytyjczyk, 78467.html.

Kryzys rządzi już rok. Pobrano z: http://www.tvn24. $\mathrm{pl} /$ raporty/kryzys-rzadzi-juz-rok,233.

Nbportal.pl (2013). deficyt strukturalny.

Obserwator finansowy.pl (2013).

Rada kredytodawców hipotecznych (CML). Pobrano z: http://www.cml.org.uk/cml/media/press/3247.

Speculative Bubble. Pobrano z: http:/fi nancial-dictionary.thefreedictionary.com/Speculative + Bubble.

Urząd Statystyczny Wielkiej Brytanii. Pobrano z: http:/www.statistics.gov.uk/hub/economy/prices-output-and-productivity/price-indices-and-inflation/ index.html. 